\title{
A novel integrated assessment framework for exploring possible futures for Australia: the GNOME.3 suite for the Australian National Outlook
}

\author{
T. S. Brinsmead $^{\text {a }}$, K. Smith ${ }^{\mathrm{b}}$, S. Hatfield-Dodds ${ }^{\text {b,c }}$, P. Adams ${ }^{\mathrm{d}}$, T. Baynes ${ }^{\mathrm{e}}$, S. Ferrier ${ }^{\mathrm{b}}$, T. Harwood ${ }^{\mathrm{b}}$, \\ J. A. Hayward ${ }^{\mathrm{a}}$, J. Lennox ${ }^{\mathrm{d}, \mathrm{f}}$ R. Marcos Martinez $^{\mathrm{b}}$, M. Nolan ${ }^{\mathrm{g}}$ and J.Qiu ${ }^{\mathrm{a}}$ \\ ${ }^{a}$ CSIRO Energy Centre, Mayfield West, New South Wales, ${ }^{b}$ affiliation at time of submission: CSIRO Land and \\ Water, Black Mountain Science \& Innovation Park, Australian Capital Territory, ${ }^{c}$ current affiliation: \\ Australian Bureau of Agricultural and Resource Economics, Canberra, Australian Capital Territory (previous \\ affiliation: $\left.{ }^{b}\right),{ }^{d}$ Centre of Policy Studies, Victoria University, Melbourne, Victoria, ${ }^{e}$ CSIRO Land and Water, \\ North Ryde, New South Wales, ${ }^{f}$ CSIRO Land and Water, Clayton, Victoria, ${ }^{g}$ CSIRO Land and Water, \\ Urrbrae, South Australia. \\ Email: thomas.brinsmead@csiro.au
}

\begin{abstract}
A more robust understanding of the implications of future risks and opportunities could improve strategic decision making at different levels. Single sector analyses are likely to simplify key interactions across domains which may limit their ability to identify mechanisms to mitigate risks or harness opportunities. This paper describes an integrated suite of a dozen global and national models for exploring Australia's future through quantitative scenario analysis, GNOME.3 (the Global and National Outlooks for Materials, Economy, Environment \& Energy).

The GNOME. 3 suite builds on the integrated suite used in the first CSIRO (Commonwealth Scientific and Industrial Research Organisation) National Outlook (Hatfield-Dodds, Adams, et al. (2015)), expanding both its robustness and depth. Expanded modelling capability in the GNOME.3 includes: a new computable general equilibrium model (GTAP-ME.3); a global and local learning (GALLM) model of transport, GALLM-T; improvements to CSIRO's global electricity model GALLM-E; and a global land use and agricultural model, the Global Biosphere Management Model (GLOBIOM), modified to separately identify Australia (GLOBIOM-Aus). GNOME.3 also provides improved ability to analyse pathways for Australia's future energy system through a new Australian energy model, AUS-TIMES. Development of computer scripts to automate interactions across core components of the modelling suite improves the transparency and efficiency of scenario analysis.

This multi-model framework is the most comprehensive scenario capability for Australia to date that connects and integrates across the three interconnected sub-systems: economic-social, environmental earth systems, and food-energy-water nexus. There are several areas-for example, assessing markets for ecosystem services, exploring the complexities of water use, and exploring potential shifts in comparative advantage - where analysis can only be obtained by cross-sector integration associated with the comprehensive model-linking approach possible with GNOME.3 and used in the Australian National Outlooks. We describe the system and identify areas for further development and application.
\end{abstract}

Keywords: Scenario modelling, global change, futures, Australia 
Brinsmead et al., A novel integrated assessment framework for exploring possible futures for Australia: the GNOME.3 suite for the Australian National Outlook

\section{INTRODUCTION}

Australian businesses, households, and policy makers wish to understand the implications of future risks and opportunities, and the relative merits of different potential responses to these. Several research exercises provide projections or scenario analysis about Australia's future in particular domains, such as the economy or greenhouse gas emissions. However these analyses can miss key interactions across domains, reducing their ability to explore material channels through which some key risks or opportunities might be mitigated or harnessed.

Here we describe a novel integrated assessment modelling framework for exploring future risks and opportunities for Australia, the Global and National Outlooks for Materials, Economy, Environment \& Energy (GNOME.3). The framework comprises a dozen global and national models, linked to deliver quantitative scenario analyses exploring Australia's future.

\section{THE INTEGRATED ASSESSMENT FRAMEWORK FOR THE FIRST AUSTRALIAN NATIONAL OUTLOOK}

The GNOME.3 suite builds on the integrated suite used in the first CSIRO (Commonwealth Scientific and Industrial Research Organisation) Australian National Outlook (the Outlook, see Hatfield-Dodds, Adams, et al. (2015)), expanding both its robustness and depth. The first Outlook explored 20 potential trajectories for Australia to provide a better understanding of Australia's physical economy. It placed a particular focus on the 'waterenergy-food nexus' and possibilities for Australia's materials and energy-intensive industries. A key finding was that sustainable resource use and economic growth can be partners rather than competitors, but that this is not inevitable. Differences in environmental performance and resource use across the scenarios were found to depend more on 'collective' decisions in the form of policies and institutional settings than on the 'private' choices of individuals or businesses (Hatfield-Dodds, Schandl, et al. (2015, pp. 51-52)).

The quantified trajectories explored in the Outlook were generated from an integrated suite of nine models, three at global scale and six at national scale. The global models provide projections for world economic growth, energy use, food production and greenhouse gas emissions. These were used as inputs into the suite of Australian economic, energy, land use and other models to explore economic activity, resource use and environmental performance for Australia (Hatfield-Dodds, McKellar, et al. (2015, pp. 98-107)).

CSIRO plans future Outlooks every three to five years (Hatfield-Dodds, Adams, et al. (2015, p. 2)), likely focusing on different issues but with continual improvements in the integrated assessment capacity. Both CSIRO and an external peer review of the first Outlook identified areas for improving the integrated assessment framework for future Outlooks and related work. The external peer review (Hatfield-Dodds, Adams, et al. (2015, p. i)) identified three main directions for further research:

1. More complete elaboration of important topic areas not addressed in detail in the first Outlook (for example, human capital and productivity, infrastructure and supply chains, natural capital, and the built environment and urban infrastructure);

2. Improving model integration and the capacity to incorporate societal adaptations through time; and

3. Given that the integrated models varied greatly in completeness and generality, further elaborating and improving some of the component models.

Hatfield-Dodds, Adams, et al. (2015, p. 30) identified several priorities for improving the framework:

4. Developing the capacity for fully-linked multi-model ensemble analysis through automation;

5. Improving the analysis of water supply and demand; and

6. Improving the analysis of sector-level climate impacts, particularly in agriculture and built assets.

To prepare the modelling suite for the second National Outlook, CSIRO prioritised the research deemed most fundamental to the capabilities of the suite: enhancing the capacity of some component models, and developing the architecture for an automated modelling suite (items 3 and 4 in the list above). In addition, we started work to elaborate other topic areas and to improve the analysis of some sector-level climate impacts (items 1 and 6). The next section gives an overview of the enhanced modelling framework, now called GNOME.3.

\section{OVERVIEW OF GNOME.3}

The GNOME. 3 suite of a dozen models builds on the integrated suite used in the first CSIRO National Outlook, expanding both its robustness and depth. Substantial improvements to the global modelling suite to improve the quality and richness of the suite's global context scenarios include: a new computable general equilibrium model, GTAP-ME.3; a new 13-region global and local learning model (GALLM) of global transport, GALLM-T; 
Brinsmead et al., A novel integrated assessment framework for exploring possible futures for Australia: the GNOME.3 suite for the Australian National Outlook

improvements to CSIRO's global electricity model GALLM-E, including an expansion to 13 regions; and the use of a global land use and agricultural model, the Global Biosphere Management Model (GLOBIOM), modified to separately identify Australia (GLOBIOM-Aus). ${ }^{1}$ The new Australian energy model, AUS-TIMES, provides improved ability to analyse pathways for Australia's future energy system. Computer scripts for automating core models in the global and national integrated assessment framework improve the transparency and efficiency of scenario analysis with the suite (Brinsmead, Baynes, and Lennox (2017); Lennox (2017)).

Figure 1 and Table 1 give an overview of the component models and key linkages in GNOME.3. The links are those currently available for use and/or that the modelling team expects to implement in the second National Outlook; section 5 identifies possible future enhancements. Figure 1 shows the domains analysed in the Outlook (energy and materials; economic activity; food and the land sector; and climate and biodiversity), the progression from global to national analysis in the modelling workflow and the three main types of information exchanged between component models (economic, technological and environmental). For example, information about the availability and cost of different energy technologies is generated in the global modelling suite, and used as an input into the national energy model. Figure 1 also shows the project logic and modelling flow for an illustrative project using the GNOME.3 suite. Using GNOME.3 for a project such as the National Outlook involves first developing scenarios (section A of Figure 1), then considering which component models should be used, and what project-specific off-models analysis is required. For example, if global biodiversity were not a key priority for a project, that model could be omitted.

\section{CONTRIBUTION OF INTEGRATED ANALYSIS TO KEY FINDINGS}

Integrated analysis can introduce new technical challenges relative to approaches with a single model or sectoral focus, but offers the benefit of generating insights that would not be possible without cross-sector integration. As results from the second Outlook are not available at the time of writing, we illustrate the importance of integrated analysis by examining key findings of the first National Outlook (Table 2). The new integrative capacity provided by the proof of concept version of GNOME. 3 is central to six of the 10 key findings from the first Outlook (darkest shaded cells in the last column of Table 2). That is, these findings and insights could not be made in a robust and defensible way without careful cross-sector integration, such as the linkages implemented in the modelling framework. For example, the finding regarding the potential for food and fibre production increases (Table 2 took into account climate impacts on agriculture, demand from the Australian transport sector for biofuels, constraints on water availability, the nature of incentives for land-based carbon sequestration, and the reservation of ecologically valuable land for biodiversity conservation.

\section{SUGGESTED AREAS FOR FUTURE RESEARCH AND APPLICATION}

As noted in section 2, CSIRO plans Outlooks on a periodic basis; each successive Outlook will focus on different issues of interest. ${ }^{2}$ Future improvements in GNOME.3 would be prioritised by criteria such as their ability to improve the robustness of results from the modelling framework or provide additional insights to questions of interest to stakeholders. The GNOME. 3 modelling team has identified research priorities for future Outlooks and other applications over the next five years, including:

- Implementing 'proof of concept' analysis of climate impacts at global scale, for example estimating climate damages at the economy-wide scale and/or to sectors such as agriculture or tourism.

- Enhancing the national scale assessment of climate impacts by expanding our analysis of trend impacts to sectors beyond agriculture, and accounting for some impacts of changes in climate variability.

- Improving the national level capacity to investigate changes in energy demand from building stock under different climate and energy policies.

- Moving from one-way to two-way links between GTAP-ME.3 and each of the GALLM models, to mirror the two-way link used between the domestic economic and energy models. This would enhance the robustness of the global economy-energy results.

- Integrating GLOBIOM-Aus with GTAP-ME.3 to improve the robustness and richness of the global agriculture and land-use sector results.

- Considering combining the global electricity and transport models to improve the robustness of interactions between the sectors, such as learning costs that incorporate battery and fuel cell costs across both sectors, and the efficient allocation of biomass and other constrained resources across the sectors.

\footnotetext{
${ }^{1}$ Citations for these and all other GNOME.3 models are in Table 1.

${ }^{2}$ A possible topic in one future Outlook - an integrated assessment of different levels of the Australian population-has been recommended to the Australian Government by the Productivity Commission (Productivity Commission (2016, pp. 39, 245, 364).
} 
Brinsmead et al., A novel integrated assessment framework for exploring possible futures for Australia: the GNOME.3 suite for the Australian National Outlook

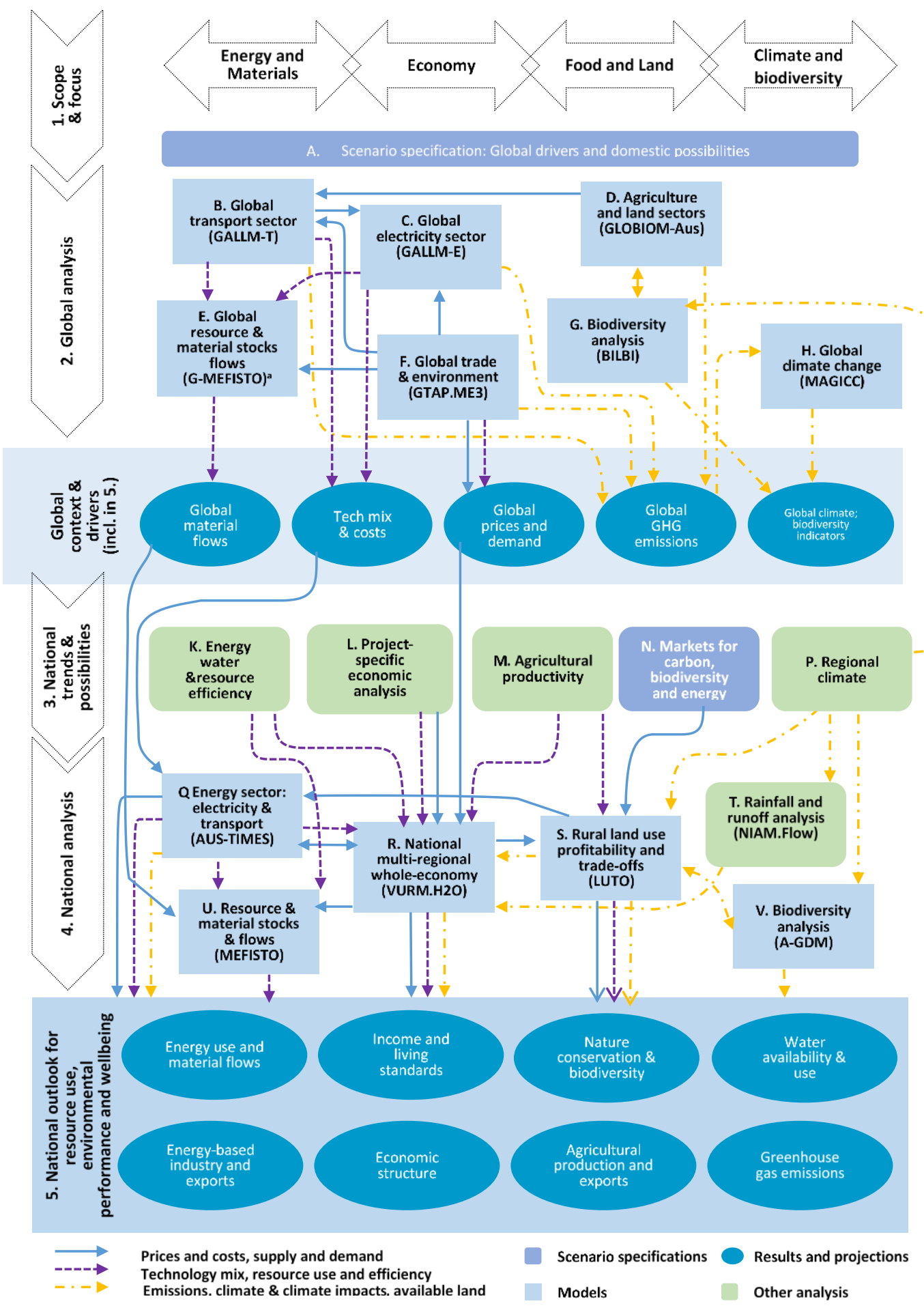

Figure 1. Component models, linkages and project logic, illustrative GNOME.3 project Note: (a) G-MEFISTO is under development 
Table 1. Summary of component models and key linkages in GNOME.3

\begin{tabular}{|c|c|c|c|}
\hline Models Letters in brackets [A]-[V] refer to Figure 1 & Key inputs & Developers and references & Model type \\
\hline $\begin{array}{l}\text { B GALLM-E, GALLM-T (Global and Local Learning Models of } \\
\text { C Electricity and Transport) are 13-region global electricity and } \\
\text { transport models. They project changes in technology costs and } \\
\text { mix, using endogenous learning curve relationships, producing } \\
\text { unique technological development paths for alternative scenarios } \\
\text { of global political, technological and economic drivers. }\end{array}$ & $\begin{array}{l}\text { Global scenario specifications [A], electricity and } \\
\text { transport demand [F], and global prices for coal, } \\
\text { oil, gas and carbon }[\mathrm{F}] \text {. }\end{array}$ & $\begin{array}{l}\text { Developed by CSIRO } \\
\text { Hayward and Graham (2013), } \\
\text { Hayward, Foster, Reedman, and Graham (2017) }\end{array}$ & $\begin{array}{l}\text { Partial equilibrium sectoral models of the } \\
\text { evolution, use, and capital and operating } \\
\text { costs of electricity generation assets } \\
\text { (GALLM-E) and transport (GALLM-T), } \\
\text { incorporating technological learning } \\
\text { (mixed integer programming). }\end{array}$ \\
\hline $\begin{array}{l}\text { D GLOBIOM-Aus (Global Biosphere Management Model-Australia) } \\
\text { is a partial equilibrium model of global agriculture and land-use } \\
\text { change with } 30 \text { world regions. }\end{array}$ & Global scenario specifications $[\mathrm{A}]$. & $\begin{array}{l}\text { Developed at the International Institute for } \\
\text { Applied Systems Analysis (IIASA) (see Havlík } \\
\text { et al. (2014)). Modified by Petr Havlík and } \\
\text { Stefan Frank at IIASA to highlight Australia and } \\
\text { adapted for GNOME.3 by Brinsmead (2017). }\end{array}$ & $\begin{array}{l}\text { Partial equilibrium model of land-use } \\
\text { based activities, including agriculture, } \\
\text { forestry and bioenergy sectors. }\end{array}$ \\
\hline 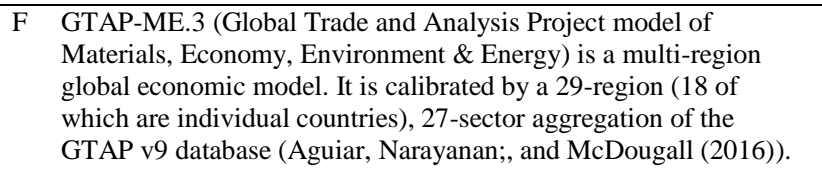 & Global scenario specifications [A]. & $\begin{array}{l}\text { Model is a modified, dynamic version of GTAP- } \\
\text { E (Burniaux and Truong (2002)) developed by } \\
\text { Philip Adams and James Lennox at the Centre of } \\
\text { Policy Studies, Victoria University, in } \\
\text { collaboration with CSIRO. }\end{array}$ & $\begin{array}{l}\text { Computable general equilibrium (CGE) } \\
\text { with detailed energy technology bundle. }\end{array}$ \\
\hline $\begin{array}{l}\text { HAGICC (Model for the Assessment of Greenhouse Gas Induced } \\
\text { Climate Change) is a reduced complexity climate model that } \\
\text { emulates the global and annual mean behaviour of significantly } \\
\text { more complex carbon-cycle models. It projects global mean } \\
\text { surface air temperature change relative to pre-industrial levels. . }\end{array}$ & $\begin{array}{l}\text { Emissions data from GALLM-E and -T [B], [C], } \\
\text { GLOBIOM-Aus [D] and GTAP.ME.3 [F]. }\end{array}$ & Meinshausen, Raper, and Wigley (2011). & $\begin{array}{l}\text { Simple (that is, reduced complexity) } \\
\text { carbon cycle-climate model. }\end{array}$ \\
\hline $\begin{array}{l}\text { Q AUS-TIMES (Australian version of The Integrated MARKAL- } \\
\text { EFOM System; is a model of the Australian energy sector with } \\
\text { detailed representation of electricity generation, transmission and } \\
\text { distribution, and transport energy use. AUS-TIMES produces } \\
\text { detailed projections of electricity prices, system costs, and the mix } \\
\text { of electricity and transport technologies and fuel use. }\end{array}$ & $\begin{array}{l}\text { Scenario specifications }[\mathrm{A}], \text { global technology } \\
{[\mathrm{B}, \mathrm{C}] \text {, fuel and carbon prices }[\mathrm{F}] \text {, together with }} \\
\text { Australian electricity and transport demand }[\mathrm{R}] \\
\text { and bioenergy supply }[\mathrm{S}] \text {. }\end{array}$ & $\begin{array}{l}\text { Developed by CSIRO in collaboration with other } \\
\text { Energy Technology Systems Analysis } \\
\text { Programme (ETSAP) partners } \\
\text { Loulou, Remne, Kanudia, Lehtila, and Goldstein } \\
\text { (2016). }\end{array}$ & $\begin{array}{l}\text { Partial equilibrium energy sector model } \\
\text { of the evolution and use of stocks of } \\
\text { generating assets and transport vehicles } \\
\text { (linear programming). }\end{array}$ \\
\hline $\begin{array}{l}\text { E MEFISTO (Material and Energy Flows Integrated with Stocks) is a } \\
\text { U multi-scale flexible modelling framework used for analysis of } \\
\text { energy and environmental pressures and supply chain or 'footprint' } \\
\text { analysis of economic production and consumption }\end{array}$ & $\begin{array}{l}\text { Vary by application; includes national } \\
\text { production, investment, consumption and trade } \\
\text { by sector }[R] \text {, energy, water and resource } \\
\text { efficiency }[\mathrm{K}] \text { and energy technology mixes }[\mathrm{Q}] \text {. }\end{array}$ & $\begin{array}{l}\text { Developed by CSIRO } \\
\text { Baynes (2015) }\end{array}$ & $\begin{array}{l}\text { Linked technology-based physical } \\
\text { stocks-and-flows model of the economy, } \\
\text { based on data from the national system of } \\
\text { accounts. }\end{array}$ \\
\hline $\begin{array}{l}\text { R VURM.H2O is a dynamic economic model, assessing greenhouse } \\
\text { emissions and policy options for seven Australian states and up to } \\
84 \text { sectors. The water extension represents water trading and three } \\
\text { supply options (rainwater, desalination, and recycled waste water). }\end{array}$ & $\begin{array}{l}\text { Global demand and prices for carbon, energy and } \\
\text { agricultural commodities [F], impacts of land-use } \\
\text { change and climate change on agricultural output } \\
{[\mathrm{S}] \text {, and streamflow inputs to water supply }[\mathrm{T}] .}\end{array}$ & $\begin{array}{l}\text { Developed by the Centre for Policy Studies at } \\
\text { Victoria University (Adams, Dixon, and } \\
\text { Horridge (2015), and used in partnership with } \\
\text { CSIRO. }\end{array}$ & $\begin{array}{l}\text { Computable general equilibrium (CGE) } \\
\text { with enhanced energy and water sector } \\
\text { detail. }\end{array}$ \\
\hline $\begin{array}{l}\text { S LUTO (Land Use Trade Offs) is a spatially detailed model that } \\
\text { calculates the relative profitability of a wide range of potential } \\
\text { Australian rural land uses. }\end{array}$ & $\begin{array}{l}\text { Global demand and prices for carbon, energy and } \\
\text { agriculture }[\mathrm{F}] \text {, climate projections (temperature } \\
\text { and rainfall) }[\mathrm{P}] \text { derived from Climate Change in } \\
\text { Australia (2017), and biodiversity priorities }[\mathrm{V}] \text {. }\end{array}$ & $\begin{array}{l}\text { Developed by CSIRO } \\
\text { Bryan et al. (2014); Connor et al. (2015) }\end{array}$ & $\begin{array}{l}\text { Integrated spatially detailed optimisation } \\
\text { model of land-use profitability and } \\
\text { dynamics. }\end{array}$ \\
\hline $\begin{array}{l}\text { G BILBI (Biogeographic modelling Infrastructure for Large-scale } \\
\text { V Biodiversity Indicators) and A-GDM (Australian GDM) analyse, } \\
\text { at global and national scales respectively, the relationship of } \\
\text { biodiversity to the physical environment over space and time, } \\
\text { using Generalised Dissimilarity Modelling, biological scaling of } \\
\text { global change to inform adaptive prioritisation and assessment. }\end{array}$ & $\begin{array}{l}\text { Beyond [A], key input is the extent and location } \\
\text { of intact habitat and new land available for } \\
\text { conservation; for A-GDM this is sourced from } \\
\text { [S]. }\end{array}$ & $\begin{array}{l}\text { These tools have been developed by CSIRO and } \\
\text { applied in a variety of collaborations. BILBI is } \\
\text { endorsed by the Convention on Biological } \\
\text { Diversity and Biological Indicators Partnership } \\
\text { Ferrier, Manion, Elith, and Richardson (2007) }\end{array}$ & $\begin{array}{l}\text { Raster model of compositional turnover } \\
\text { and persistence of vascular-plant, } \\
\text { vertebrate and invertebrate diversity as a } \\
\text { function of multidimensional } \\
\text { environment in space and time, and } \\
\text { landscape-scale habitat configuration. }\end{array}$ \\
\hline
\end{tabular}


Brinsmead et al., A novel integrated assessment framework for exploring possible futures for Australia: the GNOME.3 suite for the Australian National Outlook

In addition to future Outlooks, we identify two other broad fields of application for GNOME.3. The first is conducting National Outlooks for other countries or regions using GNOME.3's suite of global models in concert with national models from other countries or regions. The second application is providing distinctive contributions to the evidence base for meeting global challenges. As illustrated in a recent exploration of global climate mitigation and resource efficiency scenarios (Hatfield-Dodds et al. (2017)), the GNOME.3 framework is well-placed to contribute policy-relevant insights to global questions. Future applications could include the implementation of the Sustainable Development Goals and further analysis of options for low-emissions pathways in energy and land use.

Table 2. Role of integrated analysis in underpinning key findings from the first National Outlook

\begin{tabular}{|c|c|c|}
\hline Key findings (A) & $\begin{array}{l}\text { Cross-sector } \\
\text { integration }\end{array}$ & Domains involved (B) \\
\hline $\begin{array}{l}\text { While global demand for our exports is projected to treble, demand for } \\
\text { specific materials and energy exports will vary with international } \\
\text { developments. }\end{array}$ & $\begin{array}{l}\text { Previous scope } \\
\text { sufficient }\end{array}$ & $\begin{array}{l}\text { Economy - energy - emissions - land } \\
\text { use }(C)\end{array}$ \\
\hline $\begin{array}{l}\text { Australian total output of food and fibre can increase, even with significant } \\
\text { shifts of land out of agriculture. Managing the water-energy-food nexus will } \\
\text { produce challenges and opportunities for rural land use and communities (D). }\end{array}$ & $\begin{array}{l}\text { Central and } \\
\text { necessary }\end{array}$ & $\begin{array}{l}\text { Economy - land-use incentives for } \\
\text { carbon sequestration and biodiversity } \\
\text { conservation - water - climate }\end{array}$ \\
\hline Sustainability and economic growth can be partners not competitors. & $\begin{array}{l}\text { Central and } \\
\text { necessary }\end{array}$ & All \\
\hline $\begin{array}{l}\text { Living standards are set to increase, with only minor variations across } \\
\text { scenarios. }\end{array}$ & Important & All \\
\hline Electricity and transport can remain affordable. & $\begin{array}{l}\text { Previous scope } \\
\text { sufficient }\end{array}$ & Energy - economy \\
\hline Electric vehicles and biofuels could reverse mounting transport fuel imports. & Important & Energy - land use - economy \\
\hline $\begin{array}{l}\text { Collective decisions account for } 50 \%-90 \% \text { of the differences in resource use } \\
\text { and natural assets across the scenarios, with synergies in some cases and } \\
\text { trade-offs in others. }\end{array}$ & $\begin{array}{l}\text { Central and } \\
\text { necessary }\end{array}$ & All \\
\hline $\begin{array}{l}\text { While water use is projected to double by } 2050 \text {, this growth can be met while } \\
\text { enhancing urban water security and avoiding increased environmental } \\
\text { pressures. }\end{array}$ & $\begin{array}{l}\text { Central and } \\
\text { necessary }\end{array}$ & All \\
\hline $\begin{array}{l}\text { We can reduce our greenhouse gas emissions significantly, including per } \\
\text { capita emissions below the global average by } 2050 \text { in some scenarios. }\end{array}$ & $\begin{array}{l}\text { Central and } \\
\text { necessary }\end{array}$ & All \\
\hline $\begin{array}{l}\text { Incentives for voluntary land sector sequestration could be harnessed to } \\
\text { increase native habitat by } 17 \% \text { and decrease extinction risks by } 10 \% \text {, without } \\
\text { large additional government outlays. }\end{array}$ & $\begin{array}{l}\text { Central and } \\
\text { necessary }\end{array}$ & $\begin{array}{l}\text { Economy - land-use incentives for } \\
\text { carbon sequestration and biodiversity } \\
\text { conservation - water - climate }\end{array}$ \\
\hline
\end{tabular}

Source: Hatfield-Dodds, McKellar, et al. (2015, p. 112). Notes: Importance of cross-section integration for results is assessed by the source authors based on judgement and the number of sector domains involved. Dark shading indicates integration is necessary, or involves more than three sector domains, mid shading indicates it is important or involves three to four sector domains. (A) Key findings are shown in the order of the statements in the Executive summary of the first National Outlook (Hatfield-Dodds, Adams, et al. (2015, pp. i-ii)), except as noted. Some statements are treated as 'messages', involving interpretation of findings and their implications. (B) The five domains are global or national economy, water, food and land use, ecosystems and climate, energy and materials. (C) Analysis of global land use informs the level of global abatement effort, agricultural prices and energy mix. The global analysis of land use in the first National Outlook is fit for purpose, but is not as robust as the national analysis. To address this, GNOME. 3 incorporates a global land use model. (D) This finding appears before the water finding in the executive summary of the first National Outlook but has substantial overlap with the finding on agricultural output.

\section{ACKNOWLEGEMENTS}

The authors thank Karin Hosking for editing a draft, two internal and two MODSIM reviewers for helpful comments, and Paul Graham for naming GNOME.3. The authors also thank CSIRO Land and Water, CSIRO Energy and CSIRO Agriculture and Food for funding and support. 
Brinsmead et al., A novel integrated assessment framework for exploring possible futures for Australia: the GNOME.3 suite for the Australian National Outlook

\section{REFERENCES}

Adams, P. D., Dixon, J., \& Horridge, M. (2015). Victoria University Regional Model (VURM) technical documentation version 1.0, Centre of Policy Studies Working Paper G-254. Melbourne: Centre of Policy Studies, Victoria University.

Aguiar, A., Narayanan;, B., \& McDougall, R. (2016). An overview of the GTAP 9 database. Journal of Global Economic Analysis, 1(1).

Baynes, T. (2015). Assessing the potential for a step change in energy water and resource efficiency: Report for the Australian National Outlook 2015. Canberra: CSIRO.

Brinsmead, T. S. (2017). Source code: GNOME.3 GLOBIOM-Aus emulator

Brinsmead, T. S., Baynes, T., \& Lennox, J. (2017). Source code: GNOME.3 national model integration script.

Bryan, B. A., Nolan, M., Harwood, T. D., Connor, J. D., Navarro-Garcia, J., King, D., . . Hatfield-Dodds, S. (2014). Supply of carbon sequestration and biodiversity services from Australia's agricultural land under global change. Global Environmental Change, 28, 166-181.

Burniaux, J.-M., \& Truong, T. P. (2002). GTAP.E an energy environmental version of the GTAP model, GTAP technical paper No.16.

Climate Change in Australia. (2017). General Climate Model data from the Coupled Model Intercomparison Project 5. Retrieved 10 July 2017 http://dapds00.nci.org.au/thredds/catalog/ua6_4/CMIP5/derived/CMIP5/GCM/native/catalog.html

Connor, J. D., Bryan, B. A., Nolan, M., Stock, F., Gao, L., Dunstall, S., . . . Hatfield-Dodds, S. (2015). Modelling Australian land use competition and ecosystem services with food price feedbacks at high spatial resolution. Environmental Modelling \& Software, 69, 141-154.

Ferrier, S., Manion, G., Elith, J., \& Richardson, K. (2007). Using generalized dissimilarity modelling to analyse and predict patterns of beta diversity in regional biodiversity assessment. Diversity and Distributions, $13(3), 252-264$.

Hatfield-Dodds, S., Adams, P. D., Brinsmead, T. S., Bryan, B. A., Chiew, F. H. S., Finnigan, J. J., ... Wonhas, A. (2015). Australian National Outlook 2015: Economic activity, resource use, environmental performance and living standards, 1970-2050. Canberra: CSIRO.

Hatfield-Dodds, S., McKellar, L. E., Brinsmead, T. S., Bryan, B. A., Graham, P. W., Grundy, M. J., . . . Whetton, P. (2015). Australian National Outlook 2015 - Technical Report: Economic activity, resource use, environmental performance and living standards, 1970-2050. Canberra: CSIRO.

Hatfield-Dodds, S., Schandl, H., Adams, P. D., Baynes;, T. M., Brinsmead, T. S., Bryan, B. A., ... Wonhas, A. (2015). Australia is 'free to choose' economic growth and falling environmental pressures. Nature, $527,49-53$.

Hatfield-Dodds, S., Schandl, H., Newth, D., Obersteiner, M., Cai, Y., Baynes, T., . . . Havlik, P. (2017). Assessing global resource use and greenhouse emissions to 2050, with ambitious resource efficiency and climate mitigation policies. Journal of Cleaner Production, 144, 403-414.

Havlík, P., Valin, H., Herrero, M., Obersteiner, M., Schmid, E., Rufino, M. C., . . . Notenbaert, A. (2014). Climate change mitigation through livestock system transitions. Proc Natl Acad Sci U S A, 111(10), 3709-3714.

Hayward, J. A., Foster, J. D., Reedman, L., \& Graham, P. (2017). A Global and Local Learning Model of transport (GALLM-T). Paper presented at the MODSIM 2017 conference, Hobart, Tasmania.

Hayward, J. A., \& Graham, P. W. (2013). A global and local endogenous experience curve model for projecting future uptake and cost of electricity generation technologies. Energy Economics, 40, 537-548.

Lennox, J. (2017). Source code: GNOME.3 global model integration script.

Loulou, R., Remne, U., Kanudia, A., Lehtila, A., \& Goldstein, G. (2016). Documentation for the TIMES Model - PART I. ETSAP.

Meinshausen, M., Raper, S. C. B., \& Wigley, T. M. L. (2011). Emulating coupled atmosphere-ocean and carbon cycle models with a simpler model, MAGICC6 - Part 1: Model description and calibration. Atmospheric Chemistry and Physics, 11(4), 1417-1456.

Productivity Commission. (2016). Migrant Intake into Australia. Canberra: Productivity Commission. 